\title{
Peran Pendidikan dalam Membangun Kesadaran Sosial Masyarakat Bima
}

\author{
${ }^{1, *}$ Sumitro, ${ }^{2}$ Imam Yuliadi \\ 1,2 Institut Ilmu Sosial dan Ilmu Budaya Samawa Rea \\ *sumitro765@gmail.com, Imamyuliadi0@gmail.com
}

\section{Artikel Info}

Tanggal Publikasi

\section{Kata Kunci}

Peran Pendidikan

Kesadaran Sosial

Masyarakat.

\begin{abstract}
Abstrak
Penelitian bertujuan untuk mendeskripsikan kesadaran sosial masyarakat Bima selama ini, mendeskripsikan peran pendidikan dalam membangun kesadaran sosial dan mendeskripsikan korelasi pendidikan dengan kesadaran sosial pada masyarakat Bima, Khususnya Masyarakat Donggo. Jenis penelitian kualitatif dengan desain etnografi. Tempat penelitian di Kecamatan Donggo Kabupaten Bima. Waktu penelitian mulai bulan Mei sampai Juni. Subjek penelitian Tokoh adat Bima, Masyarakat Donggo, Guru dan Siswa sebagai element pendidikan. Teknik pengumpulan data menggunakan observasi, wawancara dan dokumentasi. Keabsahan data menggunakan triangulasi sumber. Teknik analisis data dengan pengumpulan data, reduksi data, penyajian data, dan kesimpulan. Hasil penelitian ini berupa peluang dalam membangun pendidikan di Bima, pertama adalah potensi independensi lembaga perguruan tinggi, dan yang kedua adalah keunggulan kuantitas kalangan akademisi.
\end{abstract}

\section{PENDAHULUAN}

Dalam kebudayaan yunani kuno, pendidikan dapat diilustrasikan sebagai pengolahan lahan pertanian dimana benih dapat tumbuh dengan baik dan menghasilkan buah. Pendidikan adalah usaha terpadu untuk memanusiakan manusia muda, membentuk karakter sehingga peserta didik menjadi pribadi yang berkeutamaan, dan budaya intelektual. Dengan kata lain, pendidikan adalah proses humanisasi, dalam arti mengolah potensi-potensi yang dimiliki seseorang untuk menjadi lebih manusiawi.

Pendidikan juga dapat dipahami sebagai proses liberasi dalam arti bahwa melalui pendidikan peserta didik mengalami proses emansipasi dan dibebaskan dari berbagai bentuk penindasan dogmatisme dan fatalisme yang melumpuhkan. Di samping itu, pendidikan dapat dijadikan sebagai wahana untuk memberdayakan peserta didik sehingga mereka dapat menjadi agen perubahan sosial. Melalui pendidikan yang transformatif dan partisipatif, peserta didik diharapkan mampu mengembangkan dimensi individual dan sosialnya secara seimbang. (Tarpin, Laurentius. 2008: 343).

Melalui pendidikan terpadu dan holistik diharapkan terbentuk manusia yang mampu menggali makna, menemukan jati diri, menyadari dan mengembangkan potensi yang dimiliki, mengendalikan naluri (libido vivendi, sexualis, dominandi et possendi), membentuk hati nurani, menumbuhkan rasa kekaguman, dan mampu mengekspresikan perasaan dan pemikirannya secara tepat dan benar. Pendidikan yang holistik akan membantu orang keluar dari perasaan ketakbermaknaan dan absurditas hidup, terutama pada saat mereka menghadapi pengalaman kontras-negatif. Ketajaman intelektual, kemampuan berimajinasi-utopistik, daya juang yang tinggi dan semangat heroik dapat dibentuk dan dilatih melalui pendidikan (Tarpin, Laurentius. 2008: 344).

Paulo Freire (2007: 5) menjelaskan definisi pendidikan dalam perpektif kritis. Dimana pendidikan di mata Freire merupakan sebuah pilot project dan agen untuk melakukan perubahan sosial guna membentuk masyarakat baru. Menjadikan pendidikan sebagai pilot project, berarti kita berbicara tentang sistem politik kebudayaan (cultural politics) yang menyeluruh dan melampaui batas teoritis dari 
doktrin politik tertentu, serta berbicara tentang keterkaitan antara teori, kenyataan sosial dan makna emansipasi yang sebenarnya. Freire memberikan definisi yang khas karena bersifat aplikatif dan sarat nilai, dimana pendidikan harus bisa membebaskan peserta didik dari belenggu kepentingan liberal \& kapitalis yang menjadikan pendidikan sebagai alat eksploitasi masal untuk kepentingan golongan tertentu.

Dalam UU No. 20 tahun 2003 tentang sistem pendidikan nasional disebutkan, "Pendidikan adalah usaha sadar dan terencana untuk mewujudkan suasana belajar dan proses pembelajaran agar peserta didik secara aktif mengembangkan potensi dirinya untuk memiliki kekuatan spiritual keagamaaan, pengendalian diri, kepribadian, kecerdasan, akhlak mulia, serta ketrampilan yang diperlukan dirinya, masyarakat, bangsa, dan Negara”. Sedangkan difinisi Pendidikan Formal berdasarkan UU No. 20 Tahun 2003, tentang Sistem Pendidikan Nasional Bab I Pasal 1 menjelaskan "Pendidikan formal adalah jalur pendidikan yang terstruktur dan berjenjang yang terdiri atas pendidikan dasar, pendidikan menengah, dan pendidikan tinggi”.

\section{METODE PENELITIAN}

Penelitian ini menggunakan pendekatan kualitatif dan kuantitatif dengan jenis deskriptif. Subjek dalam penelitian ini yaitu 28 Masyarakat Donggo Kecamatan Donggo Kabupaten Bima. Data dikumpulkan melalui wawancara dan angket. Wawancara yang digunakan yaitu wawancara tidak terstruktur sedangkangkan angket yang digunakan dengan jenis tertutup yaitu Skala Likert yang memuat pilihan jawaban "sangat setuju" dengan skor empat, "setuju” dengan skor tiga, "tidak setuju" dengan sekor dua, dan "sangat tidak setuju" dengan skor satu. Wawancara dan angket ditujukan kepada 28 orang masyarakat untuk memperoleh informasi mengenai peran pendidikan dalam membangun kesadaran sosial masyarakat Bima. Analisis data dilakukan dengan reduksi data, penyajian data dan penarikan kesimpulan. Instrumen angket yang digunakan terdiri dari 10 item.

Dalam penelitian ini menggunakan penelitian kualitatif. Sukmadinata (2012:60) mendefinisikan bahwa "Penelitian kualitatif adalah suatu penelitian yang ditunjukkan untuk mendeskripsikan dan menganalisis fenomena, peristiwa, aktfitas social, sikap, kepercayaan, persepsi, pemikiran orang secara individual maupun, kelompok. Penelitian kualitatif mempunyai dua tujuan utama yaitu, (1) menggambarkan dan mengungkapkan, (2) menggambarkan dan menjelaskan”.

Desain penelitian ini adalah etnografi. Menurut Sukmadinata (2012: 62) menyatakan bahwa "Studi etnografi mendeskripsikan dan menginterpretasikan budaya, kelompok sosial dan system". Proses penelitian etnografi dilaksanakan di lapangan dalam waktu yang cukup lama, berbentuk observasi dan wawancara secara alamiah dengan para partisipan dalam berbagai bentuk kesempatan kegiatan serta mengumpulkan dokumen-dokumen dan benda-benda.

Lokasi penelitian ini di Kabupeten Bima, tepatnya di Kecamatan Donggo, Kabupaten Bima. Masyarakat Donggo merupakan salah satu daerah yang dianggap sebagai masyarakat asli yang menempati wilayah Bima. Penelitian ini dilaksanakan selama 2 Bulan, yaitu bulan Mei sampai Juni 2019.

Data di kumpulkan dengan menggunakan tiga teknik pengumpulan data yaitu metode observasi, wawancara dan dokumentasi. Menurut Mulyatiningsih (2013: 45) menyatakan bahwa "Analisis data kualitatif dilakukan secara interaktif dan berlangsung secara terus menerus sampai tuntas, sehingga data yang diperoleh tidak jenuh dan ditemukan data baru. Kegiatan analisis data sudah dimulai sejak peneliti mengambil data sampai data penelitian selesai dikumpulkan. Model interaktif kegiatan analisis data yang dimulai dari data reduction, data display, dan conclusion drawing/verification". 
Menurut Moleong (2013: 324) untuk menetapkan keabsahan data yang diperlukan teknik pemeriksaan yang didasarkan atas kriteria: (1) derajat kepercayaan (credibility); (2) keteralihan (transferabilitas); (3) ketergantungan (dependability); (4) kepastian (confirmbility).

\section{HASIL DAN PEMBAHASAN}

\section{Konsep Kesadaran Paulo Freire}

Dunia kesadaran seseorang tidak berhenti, mandeg, ia senantiasa harus terus berproses, berkembang dan meluas, dari satu tahap ke tahap berikutnya, dari tingkat "kesadaran naif" sampai ke tingkat "kesadaran kritis", sampai akhirnya mencapai tingkat kesadaran tertinggi dan terdalam, yakni "kesadarannya kesadaran" (the consice of consciousness) (Freire, 2007: xviii). Menurut analisis Freire yang dikutip oleh Mansour Fakih bahwa ada tiga kesadaran yang menjadi turunan dari paradigma pendidikan. Tiga kesadaran tersebut adalah kesadaran magis, kesadaran naif, dan kesadaran kritis. Adapun penjelasan dari tingkat kesadaran menurut Paulo Freire tersebut adalah sebagai berikut:

1) Kesadaran Magis

Kesadaran magis (magical consciousness) adalah tingkat kesadaran manusia (masyarakat) yang tidak mampu melihat kaitan antara satu faktor dengan faktor lainnya. Terkait kesadaran magis Freire mengatakan bahwa:

“Orang yang berada pada tingkat kesadaran ini tidak bisa mengobyektifikasi fakta dan kehidupan sehari-hari yang sebetulnya mengandung permasalahan. Orang yang masih dalam tahap kesadaran ini kurang memiliki persepsi struktural, yang membentuk dan terus membentuk persepsi itu berdasarkan realitas nyata yang dipahaminya. Karena persepsi strukturalnya kurang, maka bagi mereka kenyataan adalah superrealitas atau sesuatu yang berada di luar kenyataan obyektif (Freire, 2007: 135-136)”.

Ketidakmampuan seseorang melihat hubungan peristiwa-peristiwa sosial dalam masyarakat yang mempengaruhi hidupnya membuat seseorang cenderung memaknainya secara magis. Kondisi semacam ini menimbulkan semacam bias dalam memaknai berbagai peristiwa dalam hidupnya. Seseorang pada tingkat kesadaran ini tidak mampu melihat hubungan antara struktur sosial dengan permasalahan yang dia alami. Sehingga mustahil orang pada tingkat kesadaran ini mampu untuk melawan kekuasaan atau ketidakadilan dalam suatu masyarakat.

Mengutip pernyataan Freire, William A. Smith dalam bukunya yang berjudul Concentizacao Sebagai Tujuan Pendidikan Paulo Freire menyatakan bahwa:

"Orang-orang pada tingkat kesadaran semi-transitif (kesadaran magis) tidak dapat menangkap masalah-masalah di luar pengertian kebutuhan biologis. Perhatian mereka hampir seluruhnya terpusat pada cara bertahan hidup, dan mereka tidak memiliki sense of life dalam pengertian yang lebih historis, hanya dengan pengertian ini, kesadaran semitransitif bisa mengetahui bagaimana manusia terpisah dari eksistensinya (Smith, 2008:62)”.

Ketidakberdayaan masyarakat yang memiliki kesadaran seperti ini melahirkan masyarakat yang cenderung ditindas oleh penguasa. Mereka tidak hanya kehilangan kesempatan untuk melakukan perlawanan, bahkan mereka tidak memiliki kemampuan untuk mendeskripsikan sebab dari berbagai permasalahan sosial yang mereka alami.

"Freire mengatakan bahwa, orang-orang tidak bisa membedakan antara persepsi mereka tentang obyek-obyek dari tantangan yang ditimbulkan oleh lingkungannya, sehingga mereka terjatuh pada penjelasan magis karena mereka tidak bisa menangkap kausalitas yang sebenarnya” (Maragustam, 2010:87-88) 
2) Kesadaran Naif

Perubahan dari kesadaran magis ke kesadaran naif adalah perubahan dari menyesuaikan diri dengan fakta-fakta kehidupan yang tidak terelakkan ke arah memperbaharui penyelewenganpenyelewengan yang dilakukan individu-individu dalam sebuah sistem yang pada dasarnya keras. Kesadaran naif disebut juga dengan kesadaran transisi. Pada kondisi kesadaran naif (naival consciousness) ini individu mengetahui bahwa sistem mempengaruhi dunia sosiokulturalnya, namun tidak berusaha untuk merubah sistem tersebut. Individu pada tingkat kesadaran ini cenderung berusaha menyesuaikan diri dengan sistem yang ada. Sehingga yang dilakukan oleh individu pada tingkat kesadaran ini adalah berusaha merubah dirinya, karena tidak mampu merubah sistem yang ada.

Pada tingkatan ini sudah ada kemampuan untuk mempertanyakan dan mengendalikan realitas tetapi masih ditandai dengan sikap primitif dan naif, seperti : 1) mengidentifikasikan diri dengan elit, 2) kembali ke masa lampau, 3) sikap emosi kuat, 4) banyak berpolemik dan berdebat tapi bukan berdialog

3) Kesadaran Kritis

Proses perubahan kesadaran kritis ini memiliki dua aspek, yaitu: pertama, penegasan dan penolakan individu terhadap perilaku eksploitatif penguasa, Kedua, berusaha secara sadar dan sistematis berusaha mengubah atau mengganti sistem yang menindas dengan sistem yang menurut pengetahuan mereka lebih baik. Ada pun perbedaan antara kesadaran kritis dengan kesadaran naif adalah individu pada tingkat kesadaran naif menyalahkan diri mereka sendiri. Sedangkan pada kesadaran kritis, individu-individu tidak menyalahkan dirinya sendiri, tetapi berusaha mengubah sistem sehingga bisa memaksa kaum tertindas dan penindas berkolusi (bekerja sama). Paulo Freire berkata bahwa:

"Kesadaran kritis ditandai dengan penafsiran yang mendalam atas berbagai masalah, digantikannya penjelasan magis dengan penjelasan kausalitas; dengan mencoba penemuan-penemuan yang dihasilkan seseorang; dengan keterbukaan untuk melakukan revisi; dengan usaha untuk menghindari distorsi ketika memahami masalah dan menghindari konsep-konsep yang telah diterima sebelumnya ketika menganalisis masalah; dengan menolak untuk mengubah tanggungjawab; dengan menolak sikap pasif; dengan mengemukakan pendapat; dengan mengedepankan dialog dari pada polemik; dengan menerima pandangan baru tetapi bukan sekedar sifat kebaruannya dan dengan keinginan untuk tidak menolak pandangan kuno hanya karena sifat kekunoannya -yakni dengan menerima apa yang benar menurut pandangan kuno dan baru (Smith, 2008: 80-81)".

\section{Masyarakat Bima dalam belenggu Kesadaran Naif}

Masyarakat yang berada dalam kesadaran naif cenderung melihat 'aspek manusia' sebagai akar penyebab masalah masyarakat. Sehingga dalam kesadaran naif seseorang cenderung saling menyalahkan, atau bahkan menyalahkan diri sendiri. Dalam konteks kesadaran ini seseorang tidak mempermasalahkan sistem dan struktur karena sistem dan struktur sudah dianggap benar atau tidak mampu melihat kesalahan dari sistem atau struktur yang ada.

Kendati demikian, pada tingkatan ini sudah ada kemampuan untuk mempertanyakan dan mengendalikan realitas tetapi masih ditandai dengan sikap primitif dan naif, seperti :

1) Kembali ke Masa Lampau

Konflik-konflik yang ada di Bima saat ini cenderung dihubungkan dengan konflik-konflik masa lampau. Banyak ulasan ilmiah dan hasil penelitian tentang konflik di Bima mengindikasikan 
adanya dendam masa lalu yang melatarbelakangi terjadinya konflik di Bima. Salah satu contoh konflik tersebut adalah konflik antar desa Ngali dan desa Ncera. Hasil studi doktoral yang dilakukan oleh Muhammad Natsir menunjukkan konflik tersebut telah berlangsung puluhan tahun sejak masa kesultanan. (Natsir, 2013:1)

Tidak hanya dalam konflik yang bersifat fisik, adu persepsi tentang bagaimana membangun dou labo dana (masyarakat dan pemerintahan Bima) pun sama. Golongan intelektual baru cenderung menyalahkan pihak istana (generasi kesultanan) dalam hal mengelola daerah di masa lampau. Golongan ini merasa penguasa tradisional lama telah banyak mengeksploitasi masyarakat. Pada sisi lain pihak pendukung generasi lama cenderung menuding rusaknya moral generasi muda dan berbagai kemunduran saat ini adalah karena pengaruh modernitas yang di bawa oleh generasi muda yang tidak menghargai nilai-nilai luhur budaya.

2) Sikap Emosi Kuat

Sudah bukan barang baru kalau kita lihat aksi unjuk rasa di Bima selalu berujung ricuh. Hal ini menunjukkan kondisi emosi yang kuat, gampang terprovokasi, dan kurang tenang menghadapi masalah. Kondisi psikologis yang emosional tersebut bisa pula dilihat dari seringnya sebuah konflik dalam masyarakat muncul hanya karena hal-hal sepele, misalnya; dalam sebuah acara musik dangdut perkelahian gampang sekali terjadi hanya karena saling senggol, atau saling menatap mata (dalam persepsi masyarakat Bima tatap mata / gei angi sering kali dimaknai undangan untuk berkelahi).

Dari kerangka budaya pun rekam jejak sikap emosional pun bisa ditemukan. Identifikasi diri masyarakat Bima (umum-nya generasi muda) yang menganggap dou ngau dimaknai sebagai orang yang memiliki kekuatan yang sifatnya fisik, kondisi psikologi masyarakat yang mengidentikkan maskulinitas dengan kekuatan fisik mendukung terbentuknya sikap emosi yang kuat dalam menyelesaikan berbagai masalah. Tidak heran jika pada masyarakat Bima sering terjadi konflik yang bersifat fisik.

3) Banyak Berpolemik dan Berdebat Tapi Bukan Berdialog

Kebiasaan cence ncihi (kebiasaan berdebat untuk mecari siapa yang benar) pada masyarakat Bima merupakan salah satu ciri kesadaran naif. Sejatinya iklim pendidikan mampu menciptakan suasana dialog dalam mencari jalan keluar bersama untuk masalah-masalah daerah. Alih-alih berdialog mencari solusi bersama, dalam forum-forum intelektual di Bima sekalipun sering kali kebiasaan cence ncihi berakhir dengan pertarungan ego siapa yang lebih pintar dari yang lain, kebiasaan ini juga di dukung oleh stigma dalam masyarakat yang menganggap dou ma loa ededu dou ma caru tala (orang yang pintar adalah orang yang bagus dalam beretorika/berbicara)

\section{KESIMPULAN}

Masyarakat Bima saat ini secara umum berada pada kondisi Kesadaran naif. Kondisi kesadaran seperti ini umumnya ada pada masyarakat transisi dari masyarakat tradisional yang masih memiliki kesadaran Magis menuju masyarakat modern yang seharusnya memiliki kesadaran kritis. Kondisi masyarakat peralihan adalah kondisi yang rentan, untuk itu diperlukan usaha keras untuk mempercepat terbentuknya kesadaran kritis, umumnya usaha membangun kesadaran dilakukan lewat jalur pendidikan.

Kondisi kesadaran kritis memiliki ciri sebagai berikut; 1) Melihat aspek sistem dan struktur sebagai sumber masalah, 2) Ditandai dengan kedalaman menafsirkan masalah , 3) Percaya diri dalam berdiskusi 4) Mampu menerima dan menolak, 5) Pembicaraan bersifat dialog, 6) Pada tingkat ini orang mampu merefleksi dan melihat hubungan sebab akibat. Untuk mencapai kondisi kesadaran ini diperlukan usaha membangun pendidikan kritis pada masyarakat, paulo freire dalam bukunya politik pendidikan menekankan pendidikan pada usaha mengetahui (to know). Usaha membangun kesadaran 
dalam pendidikan harus mentransendenkan semua model pendidikan sehingga model pendidikan dimana mengetahui (to know) dan merubah (to transform) realitas merupakan syarat timbal balik." (Freire, 2007: 180)

Ada dua peluang dalam membangun pendidikan di Bima, pertama adalah potensi independensi lembaga perguruan tinggi, dan yang kedua adalah keunggulan kuantitas kalangan akademisi. Dilihat dari perspektif negatif menjamurnya perguruan tinggi di daerah merupakan masalah bagi daerah, karena semakin banyak menciptakan pengangguran terdidik. Namun bila dilihat dari perspektif potensi independensi. Perguruan tinggi adalah lembaga yang paling mungkin mempertahankan idealisme pendidikannya tanpa campur tangan politik di tingkat daerah, karena berada di luar birokrasi pemerintahan daerah. Potensi ini bukan tanpa tantangan karena bisa saja oknum-oknum dalam perguruan tinggi juga memiliki kepentingan politik. Untuk itu peluang kedua menjadi sangat penting perannya baik dalam lembaga pendidikan maupun membangun kesadaran kritis dalam masyarakat.

Keunggulan kuantitas kalangan akademisi, jumlah akademisi yang banyak memberikan peluang kepada kita untuk memberikan tekanan atau kontrol kepada pihak-pihak yang memiliki kepentingan politik. Kontrol tersebut bisa dilakukan baik dalam lembaga pendidikan ataupun di luar lembaga pendidikan, lewat kegiatan tridarma perguruan tinggi di luar lingkungan kampus, yang menyentuh ranah pengabdian masyarakat atau, penelitian dan pengembangan.

Dari dua potensi itu setidaknya ada dua langkah besar yang bisa diambil, yang pertama adalah membersihkan lingkungan pendidikan dari aspek politik dengan melakukan normalisasi kehidupan akademis di kampus, dan yang kedua adalah dengan menekan pihak penguasa dengan kegiatan pendidikan di luar lingkungan kampus. Langkah ini penulis tawarkan mengingat asumsi umum yang ada dalam masyarakat Bima, bahwa penguasa adalah pihak yang susah diajak bekerja sama untuk membangun daerah.

\section{Daftar Pustaka}

BPS. 2012. Bima Dalam Angka 2012. Bima: Badan Pusat Statistik Kabupaten Bima \& CV Maharani

Freire, Paulo. 2007. Politik Pendidikan: Kebudayaan, Kekuasaan dan Pembebasan (terjemahan:Agung Prihantoro). Yogjakarta: Pustaka Pelajar

Maragustam. 2010. Mencetak Pembelajaran Menjadi Insan Paripurna (Filsafat Pendidikan Islam). Yogyakarta: Nuha Litera.

Markum, M. Enoch. 2007. Pendidikan Tinggi Dalam Perspektif Sejarah Dan Perkembangannya Di Indonesia. Jakarta: Direktorat Jenderal Pendidikan Tinggi Depertemen Pendidikan Nasional

Natsir, Muhammad. 2013. Communal Conflict Resolution Model in Bima Regency West Nusa Tenggara Province. International Journal of Education and Research, Vol. 1 No. 12 , hlm. 1- 12.

Smith, William A. 2008. Conscientizacao: Tujuan Pendidikan Pendidikan Paulo Freire (Penerjemah: Agung Prihantoro). Yogyakarta: Pustaka Pelajar

Tarpin, Laurentius. 2008. Humanisme dan Humaniora: Relevansinya Bagi Pendidikan. Editor: Bambang Sugiharto. Jogjakarta: Jalasutra

, Undang-Undang Republik Indonesia Nomor 20 Tahun 2003 Tentang Sistem Pendidikan Nasional. Bab I Pasal 1, Definisi Pendidikan.

, Undang-Undang Republik Indonesia Nomor 20 Tahun 2003 Tentang Sistem Pendidikan Nasional. Bab I Pasal 1, Definisi Pendidikan Formal. 